\title{
Respuestas de Antirrhinum majus (L.) para flor de corte al potencial osmótico de la solución nutritiva en dos estaciones de crecimiento*
}

\section{Responses of Antirrhinum majus (L.) for cut flowers to the osmotic potential of a nutrient solution in two growing seasons}

\author{
Ángel N. Rojas-Velázquez ${ }^{1 \S}$, Luis Alonso Valdez-Aguilar², Lucero del Mar Ruiz-Posadas ${ }^{3}$, Manuel Sandoval-Villa ${ }^{3}$ y Vicenzo \\ Bertolini $^{4}$ \\ 'Facultad de Agronomía, Universidad Autónoma de San Luis Potosí. Carretera San Luis Potosí, Matehuala, km 14.5 Ejido Palma de la Cruz, Soledad de Graciano \\ Sánchez, San Luis Potosí, S. L. P. A. P. 32, C. P. 78321. Tel. 444 8524056. ²Departamento de Horticultura, Universidad Autónoma Agraria Antonio Narro, Calzada \\ Antonio Narro 1923, Saltillo, Coahuila, México. C. P. 25315. Tel. 844 4110200. (luisalonso.valdez@uaaan.mx). ${ }^{3}$ Botanica y Edafología. Colegio de Postgraduados. Tel. \\ 5959520200 , Montecillo, Texcoco Estado de México (lucpo@colpos.mx).리 Colegio de la Frontera Sur, 962 6289800, Tapachula Chiapas (rtolini@ecosur.mx). ${ }^{\S}$ Autor \\ para correspondencia: angel.rojas@uaslp.mx.
}

\section{Resumen}

Debido a la limitada información para el cultivo hidropónico de perrito (Antirrhinum majus L.) se requiere de más investigación para el adecuado manejo de esta especie. En el presente estudio se utilizó un material de verano (grupo IV) serie Potomac cv. Rose, para determinar los efectos del potencial osmótico $(\mathrm{PO})$ en la solución nutritiva $(-0.036$, $-0.054,-0.072,-0.090$ y $-0.108 \mathrm{MPa}$ ) sobre la biomasa y calidad comercialen cultivos de invierno y verano. En general, la mayoría de las variables evaluadas: biomasa aérea, vida de florero, días a cosecha, y área foliar, fueron afectadas por el PO y por la estación de crecimiento. La biomasa aérea total fue mayor en el invierno comparado con el verano (20 y 12 $\mathrm{g} /$ planta respectivamente), siendo las soluciones con -0.072 y -0.090 MPa, en invierno, y -0.036 MPa en el verano, las que permitieron mayor acumulación de biomasa. Los días a cosecha aumentaron de 25 a 40 días más en invierno que en verano, en tanto que la vida de florero aumentó 5 días. $\mathrm{La}$ calidad de la Sociedad de Floristas Americanos (SAF) fue menor en el invierno ya que el tallo no alcanzó el estándar requerido, clasificándose como sofisticada. En verano todos los tratamientos obtuvieron mejor calidad (especial). En general, las plantas crecidas en veranomostraron una tendencia

\begin{abstract}
Due to the limited information for hydroponic production of snapdragon (Antirrhinum majus L.) more research is required for the proper management of this species. In this study, a summer material (group IV) Potomac series cv. Rose was used to determine the effects of the osmotic potential (OP) in the nutrient solution $(-0.036,-0.054,-0.072,-0.090$ and $-0.108 \mathrm{MPa}$ ) on biomass and commercial quality in winter and summer crops. In general, most of the evaluated variables such as biomass, vase life, days to harvest, and leaf area were affected by the PO and the growing season. The total biomass was higher in winter compared to summer (20 and $12 \mathrm{~g} /$ plant respectively), solutions with -0.072 and $-0.090 \mathrm{MPa}$, in winter, and $-0.036 \mathrm{MPa}$ in the summer, which allowed higher accumulation of biomass. The days to harvest increased from 25-40 days in the winter than in the summer, while increasing vase life 5 days. The quality of the Society of American Florists (SAF) was lower in the winter because the stem did not reach the required standard, being classified as sophisticated. In the summer all got better quality treatments (special). In general, the plants grown in the summer showed a tendency to decrease the biomass as the PO solution got negative; suggesting that at this station
\end{abstract}

\footnotetext{
* Recibido: enero de 2013

Aceptado: septiembre de 2013
} 
a disminuir la biomasa conforme se hace más negativo el PO de la solución, lo que sugiere que en esta estación se requiere de soluciones nutritivas menos concentradas. En el invierno, la biomasa tendió a aumentar ligeramente al elevarse el PO de -0.036 a - 0.072 y - $0.090 \mathrm{MPa}$, sugiriendo que en esta estación las soluciones para el óptimo crecimiento de los perritos debe ser más concentradas.

Palabras clave: cultivos de invernadero, floricultura, hidropónia, nutrición.

\section{Introducción}

El cultivo hidropónico es una tecnología que eficientiza los esquemas de producción y permite disminuir el uso de agua, fertilizantes y la contaminación de los recursos naturales (Sonneveld, 2004). Enun sistema hidropónico los nutrimentos esenciales son suministrados mediante una solución nutritiva preparada disolviendo en agua sales químicas, las cuales se disocian quedando elementos en forma iónica (Urrestarazu, 2004). Para el éxito en el cultivo hidropónico es importante considerar la composición de la solución nutritiva, la cual depende de varios factores como, entre otros, de la especie cultivada, el estado de desarrollo de la planta, el propósito comercial, el clima, la calidad del agua y la estación del año (Rouphael et al., 2006). Es por esta razón por la que no existe una formulación única de la solución nutritiva.

Steiner (1966) desarrolló un método para definir la concentración óptima de los elementos nutrimentales denominada "solución nutritiva universal". La universalidad se refiere sólo a las relaciones mutuas entre aniones y cationes, dando diferentes formulaciones al variar el potencial osmótico (PO) y el pH. Un adecuado PO de la solución nutritiva es el factor más importante para el crecimiento, desarrollo y producción de algunas especies ornamentales (Steiner, 1968; Sonneveld, 2004) y varía dependiendo de la época de cultivo. En general, se recomienda utilizar soluciones nutritivas con un PO más alto en invierno que en verano (Steiner, 1968; Salas y Urrestarazu, 2001).

El PO de la solución nutritiva afecta a las plantas dediferentes maneras. Un efecto general es el aumento del contenido de la materia seca con el incremento de la conductividad eléctrica (CE) (Sonneveld, 2004), parámetro relacionado directamente con el PO. Entre los aspectos negativos de un PO demasiado alto en especies para flor de corte es que este ocasiona una requires less concentrated nutrient solutions. In the winter, biomass tended to increase slightly to raise the PO of -0036 to -0072 and $-0090 \mathrm{MPa}$, suggesting that in this season the solutions for the optimal growth of the plants should be more concentrated.

Key words: greenhouse crops, floriculture, hydroponics, nutrition.

\section{Introduction}

Hydroponics is a technology that streamlines production schemes and helps to reduce the use of water, fertilizers and prevent the pollution of natural resources (Sonneveld, 2004). In a hydroponic system, essential nutrients are supplied via a nutrient solution made by dissolving chemical salts, which dissociate remaining elements in ionic form (Urrestarazu, 2004). For success in hydroponics is important to consider the composition of the nutrient solution, which depends on several factors including, among others, the cultivated species, the stage of development of the plant, the business purpose, climate, quality water and season (Rouphael et al., 2006). It is for this reason that there is a unique formulation of the nutrient solution.

Steiner (1966) developed a method to define the optimal concentration of nutritional elements called "universal nutrient solution." Universality refers only to the mutual relations between anions and cations, giving different formulations by varying the osmotic potential (OP) and $\mathrm{pH}$. PO Adequate nutrient solution is the most important factor for growth, development and production of ornamental species (Steiner, 1968; Sonneveld, 2004) and varies depending on the growing season. In general, we recommend using a PO nutrient solution higher in winter than in summer (Steiner, 1968; Chambers and Urrestarazu, 2001).

The nutrient solution $\mathrm{PO}$ affects plants in different ways. An overall effect is the increase of dry matter content with the increase of electrical conductivity (EC) (Sonneveld, 2004) parameter directly related to the solution. The negative aspects of a PO too high in cut flower species is that this causes a reduction in size, thereof a decrease in length and stem thickness and lack of color on the leaves (Ehret et al., 2005 ). An excessive increase in the $\mathrm{EC}$ of the nutrient solution reduces the relative growth rate, leaf area index 
reducción del tamaño de las mismas, un descenso de la longitud y grosor de tallo y falta de color de las hojas (Ehret et al., 2005). Un aumento excesivo en la CE de la solución nutritiva reduce la tasa de crecimiento relativo, el índice de área foliar (Farías et al., 2006), y el peso fresco y seco (Soneveld y Voogt, 2008). De Kreij y Van Os (1989) y Urban et al. (1995) mencionan que una alta salinidad, relacionada a su vez con una alta CE y $\mathrm{PO}$, no afecta la vida media de florero, pero en algunos casos, como en Ranunculus asiaticus, si se detectó una disminución en la vida de florero (Valdez-Aguilar et al., 2009), lo cual debe estar asociado con la toxicidad debido a iones específicos que componen la solución.

El perrito (Antirrhinum majus L.) para flor de corte es una especie de reciente ingreso al mercado de flores en México. Entre las ventajas que ofrece su cultivo es que tiene una gran variedad de colores, además de que se puede cultivar durante todo el año, debido a que está clasificado en cuatro grupos de respuesta a la temperatura y a la luz. (Miranda et al., 2008). A pesar de la información existente sobre la implementación de sistemas hidropónicos y su influencia sobre el crecimiento, desarrollo y calidad comercial en otras especies, la información para el cultivo hidropónico de perrito es escasa, por lo que se requiere de más investigación para lograr el adecuado manejo del cultivo en estos sistemas. Con base a lo anterior, el objetivo del presente estudio fue el de determinar como la acumulación de materia seca y calidad comercial de plantas de perrito son afectadas cuando son irrigadas con soluciones nutritivas de diferente $\mathrm{PO}$ en dos épocas de cultivo: verano e invierno.

\section{Materiales y métodos}

El trabajo se realizó durante 2007 a 2008, y verano en los invernaderos del Colegio de Postgraduados en el Campus Montecillo $19^{\circ} 29^{\prime}$ latitud norte y $98^{\circ} 53^{\prime}$ longitud oeste. Las condiciones ambientales durante ambas estaciones fueron, durante el invierno, temperatura media diurna y nocturna de $24^{\circ} \mathrm{Cy} 18 \mathrm{C}$, respectivamente, mientras que en el verano estas fueron $32{ }^{\circ} \mathrm{C}$ y $22^{\circ} \mathrm{C}$, respectivamente. Plántulas de perrito (Antirrhinum majus L.) de la serie Potomac cv. Rose (Pan American Seeds Co), considerado como un cultivar de verano (Grupo IV), fueron generadas de semilla y tras desarrollar dos pares de hojas verdaderas (5 semanas) se trasplantaron en tezontle rojo (roca volcánica) tamizado de 4 a $6 \mathrm{~mm}$ de diámetro. Como contenedores se usaron bolsas de polietileno negro de calibre 700 (5 L). Habiendo
(Farías et al., 2006), and fresh and dry weight (Soneveld and Voogt, 2008). De Kreij and Van Os (1989) and Urban et al. (1995) mentioned that, high salinity, connected in turn with a high CE and PO does not affect the average vase life at all, but in some cases, such as Ranunculus asiaticus, a decrease in the vase life was detected (Valdez-Aguilar et al., 2009), which must be associated with toxicity due to specific ions that compund the solution.

The snapdragon (Antirrhinum majus L.) for cut flower is kind of recent admission to the flower market in Mexico. Among the advantages of this cultivation is that it has a variety of colors, plus they can be grown all year round, because it is classified into four groups in response to temperature and light (Miranda et al., 2008). Despite the existing information on the implementation of hydroponic systems and their influence on growth, development and commercial quality in other species, information for hydroponics for the snapdragon is scarce so far, so more research is required to achieve adequate crop management in these systems. Based on the above, the objective of this study was to determine the accumulation of dry matter and plants of commercial quality affected when irrigated with nutrient solutions of different PO two growing seasons: summer and winter.

\section{Materials and methods}

The work was performed during 2007-2008, and summer in the greenhouse of the Graduate College at the Campus Montecillo, located at $19^{\circ} 29^{\prime}$ North latitude and $98^{\circ} 53^{\prime}$ West longitude. The environmental conditions during both seasons were; during the winter, average daytime and nighttime temperature of $24^{\circ} \mathrm{C}$ and $18^{\circ} \mathrm{C}$, respectively, while in the summer these were $32{ }^{\circ} \mathrm{C}$ and $22{ }^{\circ} \mathrm{C}$, respectively. Seedlings of the snapdragon (Antirrhinum majus L.) Potomac, cv Rose. (Pan American Seeds Co), considered a summer cultivar (Group IV), were generated from seeds and after developing two pairs of true leaves (5 weeks) were transplanted into red volcanic rock (volcanic rock) screening of 4-6 mm in diameter. As containers, we used black polythene bags 700 gauge (5 L). Elapse of 30 days after the transplantation, placing for tutoring plastic mesh fabric of $17.5 \times 17.5 \mathrm{~cm}$. Irrigation with nutrient solution was applied twice per day $(600 \mathrm{ml} /$ irrigation/ container) using a gravity drip system with a uniformity coefficient of $95 \%$. 
transcurrido 30 días después del trasplante, fue colocada una malla plástica para tutoreo con tejido de $17.5 \times 17.5 \mathrm{~cm}$. El riego con la solución nutritiva se aplicó dos veces por día (600 ml/riego/contenedor) mediante un sistema de goteo por gravedad con un coeficiente de uniformidad de $95 \%$.

Las soluciones nutritivas en estudio comprendieron cinco PO (-0.036, -0.054, -0.072, -0.090 y -0.108 MPa) (Cuadro 1), los cuales se basaron en la composición de la solución de Steiner (1966). Para obtener los diferentes PO se usaron concentraciones crecientes de nutrimentos ajustadas tomando en cuenta la concentración de los iones contenidos en el agua de riego, la cual tenía una conductividad eléctrica de $0.39 \mathrm{dS} \mathrm{m}^{-1}$. El pH de las soluciones se ajustó diariamente a 5.5 con $\mathrm{H}_{2} \mathrm{SO}_{4} 1 \mathrm{~N}$. Las fuentes fertilizantes utilizadas para proporcionar los macronutrimentos fueron: nitrato de calcio, nitrato de potasio, sulfato de magnesio, sulfato de potasio y fosfato monopotásico. Los micronutrimentos se suplementaron en la misma concentración en todos los tratamientos, la cual fue la siguiente (en $\mathrm{mg} \mathrm{L}^{-1}$ ): Fe 5.0, Mn 1.6, Zn 0.023, Cu 0.011 y B 0.865. Las fuentes de micronutrimentos se prepararan con las siguientes sales grado reactivo: ácido bórico, sulfato de manganeso, sulfato de zinc, sulfato de cobre, molibdato de sodio y el hierro se suministró en forma de quelato Fe-EDTA.
The nutrient solutions under study comprised five PO $(-0.036,-0.054,-0.072,-0.090$ and $-0.108 \mathrm{MPa}$ ) (Table $1)$, which were based on the composition of the solution of Steiner (1966). For different PO was used increasing concentrations of nutrients adjusted, taking into account the concentration of the ions contained in the irrigation water, which had an electrical conductivity of $0.39 \mathrm{dS} \mathrm{m}^{-1}$. The $\mathrm{pH}$ of solutions was adjusted daily to 5.5 with $\mathrm{H}_{2} \mathrm{SO}_{4} 1 \mathrm{~N}$. The fertilizer sources used to provide the macronutrients were: calcium nitrate, potassium nitrate, magnesium sulfate, potassium sulfate and potassium dihydrogen phosphate. The micronutrients were supplemented in the same concentration in all treatments, which was as follows (in $\mathrm{mg} \mathrm{L}^{-1)}: \mathrm{Fe} 5.0, \mathrm{Mn}$ $1.6, \mathrm{Zn} 0.023,0.011$ and B $0.865 \mathrm{Cu}$. Micronutrient sources are salts prepared with the following reagent grade boric acid, manganese sulfate, zinc sulfate, copper sulfate, sodium molybdate and iron supplied in the form ofFe-EDTAchelate.

Inside the greenhouse four plants per container were placed, taking 10 containers in each treatment completely random distributed, thereby had a density of 60 plants $\mathrm{m}^{-2}$. Upon completion of the experiment, the plants were dried in a forced air oven (Precision 17 GCA Corp.) at $70{ }^{\circ} \mathrm{C}$ for 48 to $72 \mathrm{~h}$, yielding a dry weight electronic balance (Explorer $0.001 \mathrm{~g}$, Ohaus Corp., USA).

Cuadro 1. Composición de las soluciones nutritivas evaluadas en el cultivo hidropónico de perrito (Antirrhinum majus L.) en invierno y verano.

Table 1. Composition of nutrient solutions evaluated in the hydroponic cultivation of the snapdragon (Antirrhinum majus L.) in winter and summer.

\begin{tabular}{cccccccccc}
\hline $\begin{array}{c}\text { Soluciones (PO) } \\
\mathrm{MPa}^{*}\end{array}$ & \multicolumn{4}{c}{ Cationes me $\mathrm{L}^{-1}$} & \multicolumn{4}{c}{ Aniones me $\mathrm{L}^{-1}$} & \multicolumn{2}{c}{$\mathrm{CE}$} \\
& $\mathrm{K}^{+}$ & $\mathrm{Ca}^{2+}$ & $\mathrm{Mg}^{2+}$ & Suma de cationes & $\mathrm{NO}_{3}^{-}$ & $\mathrm{H}_{2} \mathrm{PO}_{4}^{-}$ & $\mathrm{SO}_{4}{ }^{2-}$ & Suma de aniones & $\mathrm{dSm}^{-1}$ \\
\hline-0.036 & 3.5 & 4.5 & 2.0 & 10 & 6.0 & 0.50 & 3.5 & 10 & 1.0 \\
-0.054 & 5.25 & 6.75 & 3.0 & 15 & 9.0 & 0.75 & 5.25 & 15 & 1.5 \\
$-0.072^{\mathrm{F}}$ & 7.0 & 9.0 & 4.0 & 20 & 12 & 1.0 & 7.0 & 20 & 2.0 \\
-0.090 & 8.75 & 11.25 & 5.0 & 25 & 15 & 1.25 & 8.75 & 25 & 2.5 \\
-0.108 & 10.5 & 13.5 & 6.0 & 30 & 18 & 1.50 & 10.5 & 30 & 3.0 \\
\hline
\end{tabular}

${ }^{*} \mathrm{MPa}=10$ bares. ${ }^{\mp}$ tratamiento correspondiente a la solución de Steiner (1966)

Dentro del invernadero se colocaron cuatro plantas por contenedor, teniendo 10 contenedores en cada tratamiento distribuidos completamente al azar, con lo que se tuvo una densidad de 60 plantas $\mathrm{m}^{-2}$. Al finalizar el experimento las plantas se secaron en una estufa con aire forzado (Precisión 17 GCA Corp.) a $70{ }^{\circ} \mathrm{C}$ de 48 a 72 h, obteniéndose el peso seco con una balanza electrónica (Explorer 0.001 g, Ohaus Corp., USA).
Other variables measured were vase life, days to harvest and commercial quality according to the American Society of Florists (SAF), for which we used the fresh matter weight, stem length and number of florets. Vase life was determined in two growing seasons, for which we used 12 stems, cut at $50 \mathrm{~cm}$ in length and the sheets are removed at $15 \mathrm{~cm}$ at the baseline. Two stems were placed in clear plastic cups and one liter were added wit $500 \mathrm{ml}$ of distilled 
Otras variables que se midieron fueron la vida de florero, días a cosechay la calidad comercial según la SociedadAmericana de Floristas(SAF), para lo cual se utilizó el peso de materia fresca, longitud del tallo y el número de floretes. La vida de florero fue determinada en ambas estaciones de crecimiento, para lo cual se utilizaron 12 tallos que se cortaron a $50 \mathrm{~cm}$ de longitud y a los cuales se les removió las hojas en los $15 \mathrm{~cm}$ basales. Se colocaron dostallos en vasos de plástico transparente de un litro y se les agregó $500 \mathrm{ml}$ de agua destilada, la cual se cambiaba cada dos días. La vida de florero fue definida por el número de días de la cosecha hasta que $50 \%$ de los floretes de la espiga estuvieron abiertos y con color café.

Para el análisis estadístico se realizó un ANOVA con un modelo para un experimento bifactorial, siendo los factores la estación de crecimiento y el PO de la solución nutritiva, con 2 y 5 niveles, respectivamente. Los tratamientos contaron con 6 repeticiones para el peso seco de raíz, tallo, hojas y flores y 12 repeticiones para días a cosecha, vida de florero, y variables SAF. Se realizó; asimismo, un análisis de tendencia mediante polinomios ortogonales considerando los efectos lineal, cuadrático y cúbico. En caso de significancia estadística se aplicó una prueba de comparación de medias múltiple mediante el procedimiento de Tukey $(p<0.05)$.

\section{Resultados y discusión}

La estación de crecimiento tuvo un efecto significativo en la acumulación de biomasa total y en los órganos de la planta (Cuadro 2). En el verano, las plantas mostraron una mayor acumulación de biomasa en tallo, hojas, y espiga, superando estadísticamente a la biomasa obtenida por las plantas cultivadas en invierno, con excepción de la raíz (Figura 1). Éstos resultados coinciden con los reportados por Khattack, y Pearson (2005), y sugieren que la temperatura promedio diaria determina la tasa de desarrollo del cultivar en estudio, mientras que el fotoperiodo afecta los procesos de desarrollo. La menor temperatura prevaleciente en el invierno explicaría la menor biomasa acumulada en este cultivar durante esta estación. La mayor acumulación de biomasa en hojas y tallo durante el verano puede ser atribuida a que estos órganos presentaron una mayor demanda de fotosintatos comparado con la ejercida por espiga y raíz (Cocksull y Hughes, 1968), los cuales pueden ser suplementados durante la estación con temperatura y radiación adecuada para las plantas de un cultivar de verano como el utilizado en este estudio. water, which was changed every two days. The vase life was defined by the number of days of harvest until $50 \%$ of the florets of the spike were open and brown.

For statistical analysis, the ANOVA was performed with a model for a two-factor experiment, the factors being the growing season and the $\mathrm{PO}$ of the nutrient solution, with 2 and 5 levels, respectively. The treatments counted with 6 replicates for the dry weight of root, stem, leaves and flowers and 12 repetitions for days to harvest, vase life, and variable SAF. We performed; also a trend analysis by considering the effects orthogonal polynomials linear, quadratic and cubic. In case of statistical significance test was applied multiple means comparison using the Tukey procedure $(p<0.05)$.

\section{Results and discussion}

The growing season had a significant effect on total biomass accumulation in plant organs (Table 2). In the summer, the plants showed an increased biomass accumulation in the stem, leaf, and pin, overcoming the biomass obtained statistically by the plants grown in the winter, with the exception of the root (Figure 1). These results concord with those reported by Khattack, and Pearson (2005), and suggested that, the average daily temperature determines the rate of development of the cultivar under study, while the photoperiod affects the development processes. The lower temperature prevailing in the winter could explain the lower biomass accumulated in this cultivation for this station. The higher biomass accumulation in leaves and stems during the summer can be attributed to these organs showing higher demand compared to the photosynthate exerted by stem and root (Cocksull and Hughes, 1968), which can be supplemented during the station radiation temperature and suitable for culturing plants of a summer as used in this study.

Regardless of the growing season, the roots of the snapdragon showed reduced accumulation of biomass compared to other organs; however, the root of the plants evaluated in winter showed significantly greater accumulation assessed in the summer (Figure 1). This suggests that there is a change in the distribution of biomass in terms of the growing season, which is mainly intended to the production of stems in summer while, in the winter is directed towards the body and less for the leaves, roots 
Cuadro 2. Distribución de biomasa en plantas de perrito (Antirrhinum majus L.) serie Potomac cv. Rose irrigadas con soluciones nutritivas con diferente potencial osmótico (PO) en dos estaciones de cultivo.

Table 2. Distribution of biomass in plants of snapdragon (Antirrhinum majus L.) Potomac series cv. Rose, irrigated with nutrient solutions with different osmotic potential (OP) in two growing seasons.

\begin{tabular}{|c|c|c|c|c|c|c|}
\hline \multirow{3}{*}{$\begin{array}{l}\text { Estación } \\
\text { de cultivo }\end{array}$} & \multirow{3}{*}{$\begin{array}{c}\mathrm{PO} \\
(\mathrm{MPa})\end{array}$} & \multicolumn{5}{|c|}{ Biomasa } \\
\hline & & Hojas & Tallo & Raíz & Espiga & \multirow[t]{2}{*}{$\begin{array}{c}\text { Total } \\
\text { Aérea }\end{array}$} \\
\hline & & \multicolumn{4}{|c|}{ (gramos/planta) } & \\
\hline \multirow[t]{6}{*}{ Verano } & -0.036 & $6.72 \mathrm{a}$ & $9.86 a$ & $2.14 b$ & $7.86 a$ & $24.44 a$ \\
\hline & -0.054 & $6.24 \mathrm{a}$ & $8.81 \mathrm{ab}$ & $1.72 b$ & $5.37 \mathrm{bcd}$ & $20.42 \mathrm{ab}$ \\
\hline & -0.072 & $5.17 \mathrm{~b}$ & $7.93 b$ & $2.03 \mathrm{~b}$ & $4.51 \mathrm{cde}$ & $17.61 b c$ \\
\hline & -0.090 & $6.52 \mathrm{a}$ & $9.85 \mathrm{a}$ & $1.84 \mathrm{~b}$ & $6.48 \mathrm{ab}$ & $22.85 a$ \\
\hline & -0.108 & $6.26 \mathrm{a}$ & $8.31 b$ & $1.79 \mathrm{~b}$ & $5.66 b c$ & $20.23 \mathrm{ab}$ \\
\hline & Tendencia & $\mathrm{L}^{* *}$ & $\mathrm{~L}^{* *}$ & $\mathrm{~L} * \mathrm{C} * * *$ & $\mathrm{C}^{*}$ & $\mathrm{~L}^{*} \mathrm{C}^{*}$ \\
\hline \multirow[t]{11}{*}{ Invierno } & -0.036 & $1.93 \mathrm{c}$ & $5.06 \mathrm{c}$ & $2.04 \mathrm{~b}$ & $3.31 \mathrm{e}$ & $10.30 \mathrm{~d}$ \\
\hline & -0.054 & $2.32 \mathrm{c}$ & $5.55 \mathrm{c}$ & $2.04 b$ & $3.47 \mathrm{e}$ & $11.34 \mathrm{~d}$ \\
\hline & -0.072 & $2.39 \mathrm{c}$ & $6.28 \mathrm{c}$ & $1.99 \mathrm{~b}$ & $3.61 \mathrm{de}$ & $12.28 \mathrm{~cd}$ \\
\hline & -0.090 & $2.29 \mathrm{c}$ & $5.65 c$ & $2.86 a$ & $3.19 \mathrm{e}$ & $11.13 \mathrm{~d}$ \\
\hline & -0.108 & $2.08 \mathrm{c}$ & $5.25 \mathrm{c}$ & $1.85 \mathrm{~b}$ & $3.46 \mathrm{e}$ & $10.79 \mathrm{~d}$ \\
\hline & Tendencia & $\mathrm{L}^{* * *} \mathrm{C} * *$ & $\mathrm{~L} * \mathrm{C} * * *$ & $\mathrm{Q}^{* *}$ & $\mathrm{~L}^{* *} \mathrm{C}^{* *}$ & $\mathrm{Q}^{*}$ \\
\hline & DMS & 0.85 & 1.43 & 0.50 & 1.79 & 4.02 \\
\hline & $\mathrm{CV} \%$ & 10.64 & 10.31 & 12.76 & 19.93 & 12.30 \\
\hline & $\mathrm{PO}$ & $*$ & $*$ & $* *$ & $*$ & ns \\
\hline & Estación & $* *$ & $* *$ & $* *$ & $* *$ & $* *$ \\
\hline & Interacción & $* *$ & $* *$ & $* *$ & $* *$ & $*$ \\
\hline
\end{tabular}

Promedios seguidos de diferente letra en cada columna denotan diferencia significativa según la prueba de Tukey ( $p \leq 0.05)$. CV= coeficiente de variación; L, Q, C, tendencia lineal, cuadrática y cúbica, respectivamente. $\mathrm{DMS}=$ diferencia mínima significativa. ns; ${ }^{*}, * *, * * *$, no significativo y significativo con $\mathrm{P} \leq 0.05,0.01$, y 0.001 , respectivamente.

Independientemente de la estación de cultivo, las raíces de los perritos mostraron una menor acumulación de biomasa comparado con los restantes órganos; sin embargo, la raíz de plantas evaluadas en el invierno mostraron una acumulación significativamente mayor que las evaluadas en verano (Figura 1). Lo anterior sugiere que existe un cambio en la distribución de la biomasa en función de la estación de crecimiento, la cual es destinada preferentemente hacia la producción de tallos en el verano mientras que en el invierno se dirige menos hacia este órgano y más hacia hojas, raíces y espigas. Los cambios en la acumulación de biomasa pueden ser consecuencia de una baja capacidad de la raíz para competir por asimilados durante el verano, en comparación con la de la parte aérea de la planta (Wareing y Patrick, 1975). and spikes. Changes in biomass accumulation may result from a low capacity to compete for root assimilated during the summer, in comparison with the aerial parts of the plant (Wareing and Patrick, 1975).

The effect of PO was a significant interaction with the growing season (Table 2). Trends by reviewing PO effect of the nutrient solution in each of the growing seasons evaluated; it was observed that, during the summer, most of the biomass variables such as the total aboveground biomass (Figure 2) is decreased linearly while decreasing the PO; while in the winter there was a cubic trend increasing with decreasing biomass $\mathrm{PO}$ of -0.036 to $-0.72 \mathrm{MPa}$, but an even more negative $\mathrm{PO}$ was associated with a reduction in biomass. 


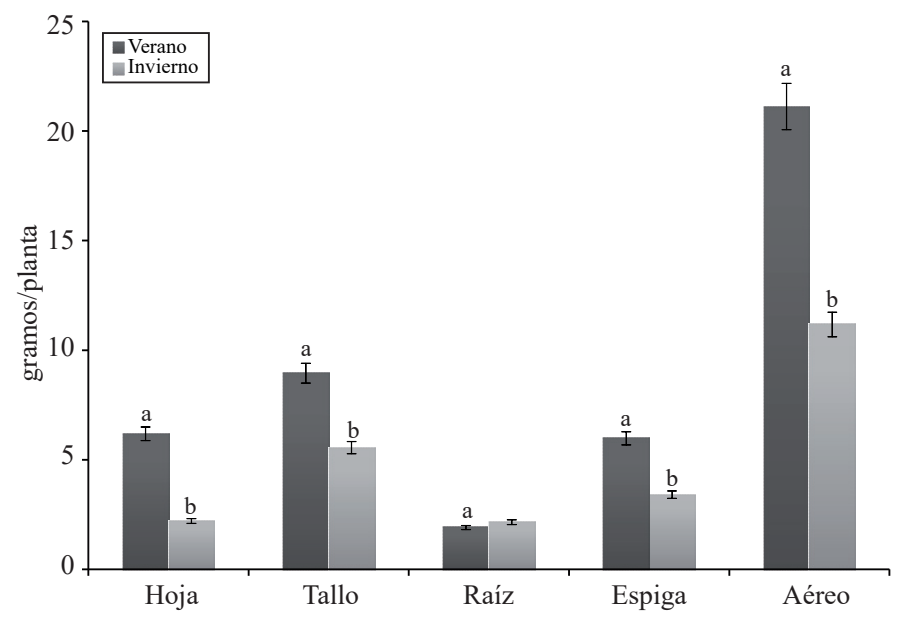

Figura 1. Efecto de la estación de cultivo en la distribución de la biomasa de plantas de perrito (Antirrhinum majus L.) serie Potomac cv. Rose irrigadas con soluciones de diferente potencial osmótico. Promedios seguidos de la misma letra indican diferencias no significativas de acuerdo a la prueba de Tukey $(\boldsymbol{p} \leq \mathbf{0 . 0 5})$. Las barras corresponden al error estándar de la media.

Figure 1. Effect of the growing season in the distribution of the biomass in snapdragon plants (Antirrhinum majus L.) Potomac series cv. Rose, irrigated with solutions of different osmotic potential. Means followed by the same letter indicate no significant differences according to the Tukey test $(\boldsymbol{p} \leq \mathbf{0 . 0 5})$. The bars correspond to the standard error of the mean.

El efecto del PO tuvo una interacción significativa con la estación de crecimiento (Cuadro 2). Revisando las tendencias por efecto del PO de la solución nutritiva en cada una de las estaciones de crecimiento evaluadas, se observó que durante el verano la mayoría de las variables de biomasa, como labiomasa total aérea (Figura 2), disminuían linealmente conforme se disminuía el PO mientras que en el invierno se observó una tendencia cúbica incrementándose la biomasa al disminuir el PO de -0.036 a $-0.72 \mathrm{MPa}$, pero un PO más negativo estuvo relacionado con una reducción en la biomasa.

En los parámetros de calidad solo se detectó significancia de la interacción en el número de floretes (Cuadro 3). En base a estos resultados se deduce que en verano se podría emplear una solución nutritiva con un PO de -0.036 MPa, lo que permitiría reducir el uso de fertilizantes sin afectar la biomasa en los diferentes órganos de las plantas. Además, con soluciones de bajo PO podría presentarse una mayor eficiencia en el uso del agua ya que en estas se presenta una menor restricción para la absorción por parte de las raíces.
In the quality parameters only significance of the interaction was detected in the number of florets (Table 3). Based on these results it follows that in the summer we could use a nutrient solution with an OP of $-0.036 \mathrm{MPa}$, thereby reducing the use of fertilizers without affecting the biomass in different plant organs. Moreover, solutions can be presented under PO of greater efficiency in the use of water as presented in these with less restriction for absorption by the roots. This would be especially important during the summer, as noted by Sonneveld (2004), in times of intense radiation EC of substrate solution by excessive evapotranspiration increases, so the OP should be decreased since high salinity restricts water absorption.

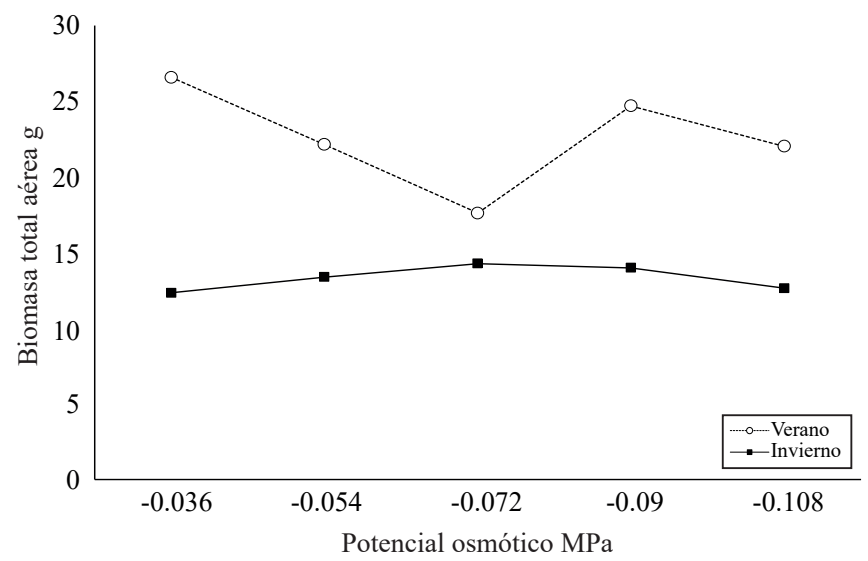

Figura 2. La interacción entre el potencial osmótico de la solución nutritiva y la estación de crecimiento en la acumulación de biomasa en plantas de perrito (Antirrhinum majus L.) cultivar 'Potomac'.

Figure 2. The interaction between the osmotic potential of the nutrient solution and the growing season in the biomass accumulation in snapdragon plants (Antirrhinum majus L.) cultivar 'Potomac'.

Salas and Urrestarazu (2001) mentioned that, in cold EC of the substrate is lower because less salts are accumulated due to reduced irrigation frequency, for this reason, we should increase the concentration of the nutrient solution to compensate the needs of plants. In this paper, during the winter biomass accumulation increased when plants were irrigated with solutions PO- 0.072 and $-0.090 \mathrm{MPa}$ (Table 2), which is also corroborated with cubic trends in these variables, which may be attributed to the increase in EC in the rhizosphere of the substrate (Schwarz and Kuchenbuch, 1997).

Regarding the days to harvesting, during the summer, the plant stems formed commercial quality 37 days earlier than plants grown in the winter (Table 3), which concords with 
Esto sería de importancia sobre todo durante el verano, como lo señala Sonneveld (2004), en épocas de intensa radiación la $\mathrm{CE}$ de la solución del sustrato aumenta por la excesiva evapotranspiración, por lo que debe disminuirse el PO de las soluciones ya que una alta salinidad restringe la absorción de agua. the findings of other authors (as), who indicated that the cultivars of Potomac series cultivated during that station enlarged 20 to 45 days the cultivation cycle (Miranda et al., 2008). In their natural habitat, snapdragons are originally long-day plants (summer flowering) and are classified as quantitative long day in response to the daily duration

Cuadro 3. Efecto del potencial osmótico (PO) de la solución nutritiva en la calidad comercial según los parámetros de la Sociedad Americana de Floristas (SAF) (biomasa fresca, numero de floretes, y longitud del tallo), además de área foliar, días a cosecha y vida de florero en plantas de perrito (Antirrhinum majus L.) cultivar 'Potomac' en dos estaciones de cultivo.

Table 3. Effect of the osmotic potential (OP) of the nutrient solution in commercial quality according to the standards of the American Society of Florists (SAF) (fresh biomass, number of florets and stem length), also leaf area, days to harvest and vase life in snapdragon plants (Antirrhinum majus L.) cultivar 'Potomac' in two growing seasons.

\begin{tabular}{|c|c|c|c|c|c|c|c|}
\hline $\begin{array}{l}\text { Estación de } \\
\text { cultivo }\end{array}$ & $\begin{array}{c}\mathrm{PO} \\
(\mathrm{MPa})\end{array}$ & $\begin{array}{l}\text { Núm. de } \\
\text { floretes (\#) }\end{array}$ & $\begin{array}{l}\text { Longitud de } \\
\text { tallo }(\mathrm{cm})\end{array}$ & $\begin{array}{l}\text { Área foliar } \\
\quad\left(\mathrm{cm}^{2}\right)\end{array}$ & $\begin{array}{c}\text { Días a cosecha } \\
\text { (días) }\end{array}$ & $\begin{array}{c}\text { Vida de } \\
\text { florero (días) }\end{array}$ & $\begin{array}{l}\text { Calidad } \\
\text { SAF }\end{array}$ \\
\hline \multirow[t]{6}{*}{ Verano } & -0.036 & $18.0 \mathrm{bc}$ & $100.0 \mathrm{a}$ & 748.7abc & $100.0 \mathrm{~b}$ & $8.00 \mathrm{c}$ & Especial \\
\hline & -0.054 & $19.7 \mathrm{ab}$ & $105.3 \mathrm{a}$ & $837.0 \mathrm{ab}$ & $104.5 b$ & $8.00 \mathrm{c}$ & Especial \\
\hline & -0.072 & $15.5 \mathrm{c}$ & $100.7 \mathrm{a}$ & $1006.1 \mathrm{a}$ & $100.7 \mathrm{~b}$ & $10.16 b c$ & Especial \\
\hline & -0.090 & $22.2 \mathrm{a}$ & $105.2 \mathrm{a}$ & $1035.0 \mathrm{a}$ & $102.5 b$ & $12.50 \mathrm{ab}$ & Especial \\
\hline & -0.108 & $20.2 \mathrm{ab}$ & $104.5 \mathrm{a}$ & $1001.5 \mathrm{a}$ & $104.5 b$ & $9.66 \mathrm{bc}$ & Especial \\
\hline & Tendencia & $C^{*}$ & $\mathrm{~L}^{*}$ & $\mathrm{~L}^{*} \mathrm{C}^{*}$ & ns & ns & \\
\hline \multirow[t]{13}{*}{ Invierno } & -0.036 & $19.3 \mathrm{ab}$ & $83.3 \mathrm{~b}$ & $594.5 b c$ & $139.7 \mathrm{a}$ & $15.00 \mathrm{a}$ & Sofisticada \\
\hline & -0.054 & $17.8 \mathrm{bc}$ & $83.2 \mathrm{~b}$ & $512.1 \mathrm{c}$ & $140.0 \mathrm{a}$ & $14.00 \mathrm{a}$ & Sofisticada \\
\hline & -0.072 & $17.8 \mathrm{bc}$ & $81.3 b$ & $545.6 \mathrm{bc}$ & $138.3 \mathrm{a}$ & $14.66 \mathrm{a}$ & Sofisticada \\
\hline & -0.090 & $19.7 \mathrm{ab}$ & $83.9 b$ & $559.5 \mathrm{bc}$ & $139.0 \mathrm{a}$ & $15.33 \mathrm{a}$ & Sofisticada \\
\hline & -0.108 & $17.8 \mathrm{bc}$ & $77.3 b$ & $472.1 \mathrm{c}$ & $139.3 \mathrm{a}$ & $14.33 \mathrm{a}$ & Sofisticada \\
\hline & Tendencia & $\mathrm{C}^{*}$ & $\mathrm{~L}^{*}$ & $\mathrm{~L}^{*} \mathrm{C}^{*}$ & ns & ns & \\
\hline & DMS & 3.15 & 8.34 & 321.9 & 6.3 & 3.35 & \\
\hline & $\mathrm{CV}$ & 8.76 & 4.72 & 23.0 & 2.74 & 14.41 & \\
\hline & $\mathrm{PO}$ & $* * *$ & ns & ns & ns & $* *$ & \\
\hline & Verano & $19.10 \mathrm{a}$ & $103.1 \mathrm{a}$ & $925.7 \mathrm{a}$ & $102.6 \mathrm{~b}$ & $9.66 \mathrm{~b}$ & \\
\hline & Invierno & $18.50 \mathrm{a}$ & $81.8 \mathrm{~b}$ & $536.8 \mathrm{~b}$ & $139.3 \mathrm{a}$ & $14.66 \mathrm{a}$ & \\
\hline & DMS & 0.85 & 2.27 & 87.3 & 1.72 & 0.91 & \\
\hline & Interacción & $* * *$ & ns & ns & ns & ns & \\
\hline
\end{tabular}

Letras con diferente valor en cada columna denotan diferencia significativa, según la prueba de Tukey $(p \leq 0.05)$. CV= coeficiente de variación; L, Q, C, tendencia lineal, cuadrática y cúbica, respectivamente. DMS = diferencia mínima significativa. ns; ${ }^{*}, * *, * * *$, no significativo y significativo con $p \leq 0.05,0.01$, y 0.001 , respectivamente.

Salas y Urrestarazu (2001) mencionan que en épocas frías la CE del sustrato es menor puesto que se acumulan menos sales debido a la menor frecuencia de riego; por esta razón, se debe aumentar la concentración de la solución nutritiva para compensar las necesidades de las plantas. En el presente trabajo, durante el invierno la acumulación de biomasa en perritos se incrementó cuando fueron irrigadas con soluciones con un PO de -0.072 y -0.090 MPa (Cuadro 2), lo cual es of the light (Hedley, 1974). Long days accelerate flowering in most cultivars while short days delay, but not completely avoided (Noto and Romano, 1989).

Plants grown in the summer developed a significantly higher leafarea compared with those grown during the winter (Table 3 ). Developing a larger canopy can mean an increase in the total chlorophyll content, which is reflected in increased 
también corroborado con las tendencias cubicas en estas variables, pudiendo atribuirse esto al incremento de la CE en la rizósfera en el sustrato (Schwarz y Kuchenbuch, 1997).

En lo referente a días a cosecha, en el verano las plantas formaron tallos de calidad comercial 37 días antes que las plantas crecidas durante el invierno (Cuadro 3), lo cual coincide con lo observado por otros autores(as), quienes indican que cultivares de la serie Potomac cultivados durante esa estación alargaron de 20 a 45 días su ciclo de cultivo (Miranda et al., 2008). En su hábitat natural, los perritos originalmente son plantas de día largo (de floración en el verano) y se clasifican como cuantitativas de día largo en su respuesta a la duración diaria de luz (Hedley, 1974). Los días largos aceleran la floración en la mayoría de los cultivares en tanto que los días cortos la retardan, pero no la evitan completamente (Noto y Romano, 1989).

En plantas cultivadas en el verano desarrollaron unárea foliar significativamente mayor en comparación con la de las plantas de invierno (Cuadro 3). El desarrollo de una mayor cubierta foliar puede significar un aumento en el contenido total de clorofila, lo que se refleja en una mayor actividad fotosintética y consecuente acumulación de biomasa (Reyes-Santamaría et al., 2000), como se pudo observar en las plantas de verano. Reyes-Santamaría et al.(2000) indican que un aumento en el área foliar se correlaciona positivamente con la producción de biomasa y la consecuente actividad fotosintética. En el presente estudio, las plantas desarrolladas en verano mostraron un aumento significativo en el área foliar conforme se elevó el PO de la solución nutritiva, mientras que en el invierno la elevación del PO estuvo asociada con una disminución en el área foliar (Cuadro 3).

La longitud del tallo en plantas cultivadas durante el verano mostró una tendencia similar al área foliar ya que esta fue mayor que las de invierno, aunque no se detectó significancia por efecto delPO(Cuadro3). Esto coincide con lo reportado por Notoy Romano (1989) quienes indican que el alargamiento del tallo fue mayor y el botón visible se alcanzó precozmente cuando los perritos eran crecidos en condiciones de día largo. En contraste, Cavins et al. (2000) y Reyes et al. (2009) mencionaron que en perritos la producción en bajas temperaturas aumentarón la longitud del tallo.

La vida en florero fue significativamente más prolongada en plantas cultivadas durante el invierno comparado con el verano, sin embargo, no se detectó un efecto significativo del PO de la solución nutritiva (Cuadro 3). Reportes similares photosynthetic activity and consequent accumulation of biomass (Reyes-Santamaría et al., 2000), as observed in plants during the summer. Reyes-Santamaría et al. (2000) indicated that an increase in the leaf area is positively correlated with the production of biomass and subsequent photosynthetic activity. In the present study, the plants grown in the summer showed a significant increase in leaf area, increased as the PO of the nutrient solution, while in the winter, PO elevation was associated with a decrease in leaf area (Table 3 ).

The stem length in plants grown during the summer showed a similar trend as the leaf area was larger than those grown during the winter, but no significance was detected by the effect of PO(Table 3 ). This is consistent with that reported by Noto and Romano (1989) who indicated that stem elongation was higher and reached in early visible buttons, when the plants were grown in long-day conditions. In contrast, Cavins et al. (2000) and Reyes et al. (2009) reported that in snapdragon plants at low temperature the production increased their stem length.

The vase life was significantly longer in plants grown during the winter $v s$ summer; however, no significant effect was detected in the PO nutrient solution (Table 3). Similar reports have been published by De Kreij and Van Os (1989) in gerbera and Urban et al. (1995) in rose, who indicated that, the salinity in the solution, which is associated with a high PO does not affect the average-life in the vase. In terms of commercial quality (Table 3 ) is negatively affected the winter season as they fell to the second category (sophisticated) because stem length did not exceed 91 $\mathrm{cm}$ required to be considered as special, the highest of all categories (Miranda et al. 2008). In contrast, in the summer a better rating (special) was obtained because the stem length and fresh biomass and the number of florets were above the requirements demanded.

\section{Conclusion}

Over all, the snapdragon plants were affected by the PO, the best response was obtained when the solutions had a pressure of -0.072 and $-0.090 \mathrm{MPa}$ in the winter. In the summer, it was more convenient a solution with a PO of $-0.036 \mathrm{MPa}$, because with this, the results are similar to those achieved with higher PO solutions. The growing season had a marked effect on the development of the 
han sido publicados por De Kreij y Van Os (1989)en gerbera y Urban et al. (1995) en rosa, quienes indicaron que la salinidad en la solución, la cual está asociada con un alto PO de la misma, no afecta la vida media en el florero. En cuanto a la calidad comercial (Cuadro3) está se vio afectada negativamente en la estación de invierno ya que se redujo a la segunda categoría (sofisticada) debido a que la longitud del tallo no fue mayor de $l o s 91 \mathrm{~cm}$ requeridos para considerarse como especial, la más alta de todas las categorías (Miranda et al. 2008). En cambio, en el verano se obtuvo una mejor clasificación (especial) porque tanto en longitud de tallo, biomasa fresca y número de floretes estuvieron por encima de los requerimientos demandados.

\section{Conclusión}

En general, las plantas de perritos fueron afectadas por el PO, obteniéndose la mejor respuesta cuando las soluciones tenían una presión de -0.072 y -0.090 MPa en invierno. En el verano, resultó más conveniente la solución con un PO de $-0.036 \mathrm{MPa}$ pues con esta se obtienen resultados similares a los logrados con soluciones de mayor PO. La estación de crecimiento tuvo un efecto marcado sobre el desarrollo de las plantas, las cuales resultaron con mayor biomasa, longitud del tallo y área foliar en el verano, además de una mejor calidad de tallos y precocidad de la floración.

\section{Literatura citada}

Cavins, T. J.; Dole, J. M. and Stamback. V. 2000. Unheatedand minimally heated winter greenhouse production of specialty cut flowers. HortTechnology. 10:793-799.

Cockshull, K. E. and Hughes, A. P. 1968. Accumulation of dry matter by Chrysanthemum morifolium after flower removal. Nature. 217:979-980.

De Kreij, C. and Van Os, P. C. 1989. Production and quality of gerbera in rockwool as affected by electrical conductivity of the nutrient solution. $7^{\text {th }}$ International Congress on Soiless Culture, Flevohof. The Netherlands. 255-264.

Farías-Arias, A.; Chaparro-Torres, L. A.; Flórez-Roncacnio, V. J. and Chaves-Córdoba, B. 2006. Growth rates of rose cv. 'Charlotte' in both soil and soilless crop systems in the Bogotá plateau, Colombia. Acta Horticulturae. 718:607-614.

Ehret, D. L., J. G. Menzies, T. Helmer. 2005. Production and quality of greenhouse roses in recirculating nutrient systems. Sci. Hort.106:103-113.

Hedley, C. L. 1974. Response to light intensity and day-length of two contrasting flower varieties of Antirrhinum majus L., J. Hortic. Sci. Biotechnol. 49:105-112. plants, which resulted in higher biomass, stem length and leaf area in the summer, and a better quality of stems and earliness of flowering.

End of the English version

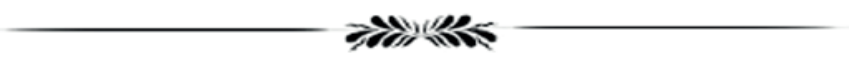

Khattack, A. M. and Pearson, S. 2005. Light quality and temperature effects on anthirrinum growth and development. J. Zheijiang University Science. 6:119-124.

Miranda-Medina, A.; Gutiérrez-Espinosa, J. A.; Colinas-León, M. T.; Arévalo-Galarza,L. and Gaytán-Acuña,E.A.2008. Producción invernal de perrito de corte (Antirrhinum majus L.) en el Valle de México. Rev. Fitotec. Mex. 31:251-256.

Noto, G. and Romano, D. 1989. Timing of snapdragon (Antirrhinum majus L.) in cold greenhouse cultivation. Acta Horticulturae. 246:175-181.

Reyes-Montero, J. A.; Gutiérrez-Espinosa, J. A.; García-Villanueva E.; Carrillo-Salazar, J. A.; Aguilar-Luna, J. M. E. y GaytánAcuña, E. A. 2009. Desarrollo y calidad de inflorescencias de Antirrhinum majus L. cultivados en intemperie. Rev. Chapingo Serie Horticultura. 15:57-60.

Reyes-Santamaría,M.I.; Villegas-Monter,A.; Colinas-LeónM.T.yCalderónZavala, G. 2000. Peso específico, contenido de proteína y de clorofila, en hojas de naranjo y tangerino. Agrociencia. 34:49-55.

Rouphael, Y.; Cardarelli, M.; Rea, E.; Battistelli, A. and Colla, G. 2006. Comparison of the subirrigation and drip-irrigation systems for greenhouse zucchini squash production using saline and nonsaline nutrient solutions. Agric. Water Management. 82:99-117.

Salas, M. C. y Urrestarazu, M. 2001. Técnicas de fertirrigación en cultivo sin suelo. Manuales de la Universidad de Almeria, Servicios y Publicaciones de la Universidad de Almeria. España.

Schwarz, D. and Kuchenbuch, K. 1997. Growth analysis of tomato in a closed recirculating system in relation to the EC-value nutrient solution. Acta Horticulturae. 450:169-176.

Sonneveld, C. 2004. La nutrición mineral y salinidad en los cultivos sin suelo: su manejo. In: Urrestarasu, G. M. (Ed.). Tratado de cultivo sin suelo. Ediciones Mundi-Prensa. España. 305-368 pp.

Sonneveld, C. and Voogt, W. 2008. Nutrient concentrations of plant tissues of greenhouse crops as affected by the EC of the external nutrient solution. Acta Horticulturae. 779:313-320.

Steiner, A. A. 1966. The influence of the chemical composition of a nutrient solution on the production of tomato plants. Plant and Soil. 24:454-466.

Steiner, A. A. 1968. Soiles culture. Proceding of the $6^{\text {th }}$ colloquium of International Potash Institute. Florence Italy. Published by: Int. Potash Inst. Berne Switzerland. 324-341 pp.

Urban, I.; Brun, R. and Urban, L. 1995. Influence of electrical conductivity, relative humidity and seasonal variations of the behaviour of cut roses producedin soiless culture.ActaHorticulturae. 408:101-107.

Urrestarazu, G. M. 2004. Tratado de cultivo sin suelo. Ediciones MundiPrensa. España.

Valdez-Aguilar L. A.; Grieve C. M. and Poss, J. 2009. Hypersensitivity of Ranunculus asiaticus to salinity and alkaline $\mathrm{pH}$ in Irrigation water in sand cultures. HortScience. 44:138-144.

Wareing P. F. and Patrick, J. 1975. Source-sink relations and the partition of assimilates in the plant. In: Cooper, J.P. (Ed.). Phtosynthesis and productivity in different environments. Cambridge University Press. 481-499p. 